\title{
EFFECT OF SOME AGRONOMIC PRACTICES ON THE INFESTATION WITH THE SUGAR CANE STEM BORER, Sesamia cretica LED. ( LEPIDOPTERA : NOCTUIDAE). Awadalla, S. S.*; F. E. Abdallah ${ }^{\star \star}$ and Nora R. El-Mashaly** * Economic Entomology Dept., Fac. of Agric., Mansoura Univ. ** Plant Protection Research Institute, Sakha Agric. Research Station
}

\begin{abstract}
The present experiments were carried out at the experimental farm of Sakha Agricultural Research Station, Kafr El-Sheikh Governorate during two successive seasons, 2006 and 2007 to study the effects of some cultural practices i.e, planting dates, nitrogen fertilizer levels and planting spaces on the infestation with the sugar cane stem borer, Sesamia cretica Led. (Lepidoptera : Noctuidae). Corn plants sown in April plantation received the maximum numbers of the borer larvae with an average number of $23.5 \pm 5.5$ and $28.7 \pm 5.8$ larvae / 5 plants, while those sown in June plantation had the least numbers of the insect larvae with an average of $3.7 \pm 0.9$ and $6.8 \pm 1.5$ larvae / 5 plants. The plantation sown in July was intermediate with an average of $8.1 \pm 2.1$ and $9.6 \pm 2.8$ larvae / 5 plants during two successive seasons, 2006 and 2007 respectively. The statistical analysis revealed that, highly significant differences in the numbers of $S$. cretica larvae in the three planting dates during both seasons.

Increasing nitrogen fertilizer rates from zero to $360 \mathrm{Kg} / \mathrm{fed}$. Caused a significant increase in rate of infestation with $S$. cretica. When suppling the corn plants with 360, 260, 160 and zero $\mathrm{Kg}$ nitrogen / fed., the rate of infestation with $S$. cretic were $(26.5 \pm 6.4 \%-24.6 \pm 7.1 \%),(15.0 \pm 3.9 \%-17.7 \pm 5.0 \%),(13.5 \pm 3.9 \%-$ $14.6 \pm 4.5 \%)$ and $(7.7 \pm 1.9 \%-10.1 \pm 3.3 \%)$ to four nitrogen levels during two seasons 2006 and 2007, respectively. The statistical analysis revealed that, in season 2006, there was highly significant differences in infestation with $S$. cretica among four rates of nitrogen fertilizer. On the other hand, there was significant differences between four rates of nitrogen fertilizer in 2007 season.

Increasing planting spaces from 20 to $30 \mathrm{~cm}$ between hills caused insignificant decrease in the rates of infestation. The rates of infestation were $(16.3 \pm 4.9 \%-16.3 \pm 5.1 \%),(10.7 \pm 3.0 \%-12.3 \pm 4.0 \%)$ and $(9.0 \pm 2.4 \%-9.7 \pm 2.9 \%)$ to three planting spaces 20,25 and $30 \mathrm{~cm}$ during two seasons 2006 and 2007 respectively. The statistical analysis revealed insignificant differences among the three planting spaces during both seasons.
\end{abstract}

\section{INTRODUCTION}

The sugar cane stem borer, Sesamia cretica is of economic importance on corn plants in Egypt, as well as allover the world. Its larvae attack young plants causing leaf feeding and dead heart symptoms ( ElNaggar, 1991).

From the available literature, some authors have studied the relationship between the planting date and the population abundance of $S$. cretica. In Egypt, Abd El-Rahim et al. and El-Naggar (1991), Abd El-Gayed (1995), El-Sappagh (1998), Ahmed and El-Saadany et al.(2000), Metwally 
(2002) and in Pakistan, Atiyeh (1996) found that, the early plantation (April) received high rates of infestation with $S$. cretica.

On the other hand, From the available literature some authors have studied the relationship between nitrogen fertilizer level and S. cretica infestation. In Egypt, Nawar et al. (1992), Galal et al. (1997), Ali et al. (2001) and Abazied (2008) found that, increasing nitrogen level causes increase in the infestation rate with this insect pest.

While, a few authors studied the relationship between planting spaces and S. cretica infestation. In Egypt, Tantawi et al. (1991) and Abazied (2008) found that, crowdness of plants in the field increases the borer infestation.

This work is aimed to study the relationship of certain agricultural practices; planting date, nitrogen fertilizer and planting spaces and S. cretica infestation on corn plants at Kafr El-Sheikh Governorate for two successive seasons; 2006 and 2007.

\section{MATERIALS AND METHODS}

The present experiments were carried out at the experimental farm of Sakha Agricultural Research station, Kafr El-Sheikh Governorate during two successive seasons, 2006 and 2007 to study the effects of some cultural practices i.e, planting dates, nitrogen fertilizer levels and planting spaces on the sugar cane stem borer, S. cretica Led. All treatments received the ordinary cultural practices, and no insecticides were used in the two seasons.

\section{Effect of planting dates}

Three planting dates were carried out. The first (April plantation) was planted on $20^{\text {th }}$ of April, the second (June plantation or the recommended planting date) was on first of June, and the third (July plantation) was on $20^{\text {th }}$ July. Giza 2 maize cultivar was used in the three planting dates and each date was divided into four replicates. From each corn plantation, twenty plants were sampled weekly for examination starting two weeks after planting until harvesting in the three dates. In each of the weekly samples, five plants were chosen at random from each of the four plots.

\section{Effect of Nitrogen fertilizer levels}

An experiment was conducted on corn plants sown on $20^{\text {th }}$ April during two successive seasons 2006 and 2007. This plantation was selected as the observations indicated that it had the highest borer damage. The infestation of corn plants with the pest was compared in plots treated with urea $(46 \%$ nitrogen) and other plots having no nitrogen fertilizer. The experiment was divided into 16 plots arranged in a Completely Randomized Design. Three nitrogen fertilizer levels with four replicates each were used. Urea was used at three levels 360,260 and $160 \mathrm{~kg}(166,120$ and 74 units ) urea /feddan, respectively. Four plots were left without fertilizer as a control. The quantity of fertilizers was added to plants as two equal splits, the first was added three weeks after planting date, and the second was added two weeks later (after 
36 days from planting). No pesticides were applied. The weekly examinations started two weeks after sowing. Samples were taken from each treatment ( nitrogen fertilizer level) and the percentage of infestation was calculated according to the following formula:

$\%$ of infestation = No. of infested plants $\times 100$

Total no. of inspected plants

\section{Effect of planting spaces}

Corn plants were sown on $20^{\text {th }}$ of April in 2006 and 2007 seasons. The spaces between hills were 20,25 and $30 \mathrm{~cm}$ (the spaces between rows were $70 \mathrm{~cm}$ ). The weekly examinations started two weeks after sowing. Samples were taken from each treatment to calculate the percentage of infestation according to the following formula.

$\%$ of infestation $=\frac{\text { No. of infested plants }}{\text { Total no. of inspected plants }} \times 100$

\section{RESULTS AND DISCUSSION}

\section{Effect of planting dates}

Data represented in Fig (1) shows the population abundance of $S$. cretica larvae in three planting dates in season 2006 and it was observed that, in April plantation, after two weeks from planting, one larva / 5 plants was recorded on May $4^{\text {th }}$, then the population tended to increase reaching its peak of 16 larvae / 5 plants on May $25^{\text {th }}, 2006$. In June plantation (recommended date), $S$. cretica larvae were detected on corn plants after three weeks from planting and 0.3 larvae / 5 plants were recorded on June $22^{\text {nd }}$. The average number of larvae reached a maximum with an average of 2.8 larvae / 5 plants on June $29^{\text {th }}$, and then the numbers declined till the end of the season. In July plantation, larvae of $S$. cretica began to appear on corn plants on August $3^{\text {rd }}$ with an average of 1.8 larvae / 5 plants . A peak of 6.8 larvae / 5 plants was recorded on August $17^{\text {th }}$, then the population decreased until the end of the season.

The data illustrated in Fig (2) shows the population abundance of $S$. cretica larvae in three planting dates in season 2007 and it was noticed that, in April plantation, larvae of $S$. cretica appeared on May $11^{\text {th }}$ with an average of 1.8 larvae /5 plants. Two peaks of 18.8 and 15.5 larvae / 5 plants were obtained on May $25^{\text {th }}$ and June $22^{\text {nd }}$, respectively. In June plantation, the mean number of $S$. cretica Larvae appeared on June $22^{\text {nd }}$ as one larva / 5 plants and reached a peak of 5.3 larvae / 5 plants on July $6^{\text {th }}$. In July plantation, larvae began to attack the plants in the beginning of August till the end of the season. The highest population density (8.8 larvae / 5 plants) was recorded on August $17^{\text {th }}$. 
Data presented in table (1) show the monthly average numbers of larvae in the different planting dates during two successive seasons of study 2006 and 2007. It can be noticed that, the highest average numbers of larvae during April plantation were in June recording $38.2 \pm 6.3$ and $48.0 \pm 4.6$ larvae / 5 plants in the two successive seasons 2006 and 2007 respectively. In June plantation, the highest average numbers of larvae were $4.8 \pm 2.3$ larvae / 5 plants recorded in August, 2006. while it was 13.5 \pm 2.6 larvae / 5 plants recorded in July, 2007. In July plantation, the highest average numbers of

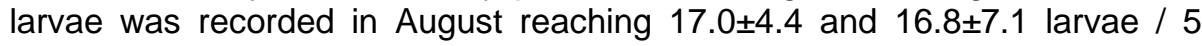
plants during 2006 and 2007 respectively.

As a conclusion, data represented in Fig. ( 1and 2) and table (1) indicated that, corn plants sown in April plantation received the maximum numbers of the sugar cane stem borer, $S$. cretica with an average number of $23.5 \pm 5.5$ and $28.7 \pm 5.8$ larvae / 5 plants, while those sown in June plantation were subjected to the least numbers of the insect larvae with an average of $3.7 \pm 0.9$ and $6.8 \pm 1.5$ larvae / 5 plants. The plantation sown in July was intermediate with an average of $8.1 \pm 2.1$ and $9.6 \pm 2.8$ larvae / 5 plants during two successive seasons, 2006 and 2007 respectively. The statistical analysis revealed highly significant differences in the numbers of $S$. cretica larvae in the three planting dates during both seasons.

The above mentioned results are in agreement with those obtained by Abdalla and Bleih (1994) who recorded two peaks of S. cretica during the third week of May and the second in the third week of September at Kafr ElSheikh region. Abd El-Gayed (1995) found that the infestation with S. cretica began after one week of sowing. Abd El-Rahman et al.(1984) reported that $S$. cretica had two annual generations; The first was the major one and heavily infested April plantation. Ahmed (2000) reported that April plantations received the maximum infestation with $S$. cretica, perhaps May and June plantations received very slight infestation and increased again in July plantation. Metwally (2002) found that maize plants sown in April received the maximum infestation with this borer. Maize plants sown in July received slight infestation by this borer.

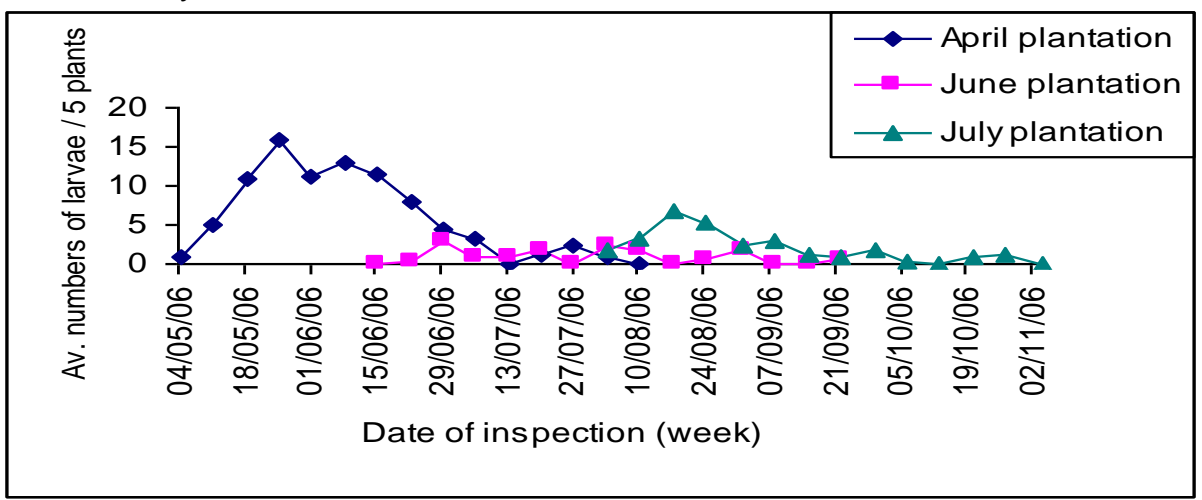

Fig (1) : Population abundance of the sugar cane stem borer, $S$. cretica larvae / 5 plants in three planting dates during 2006 season. 


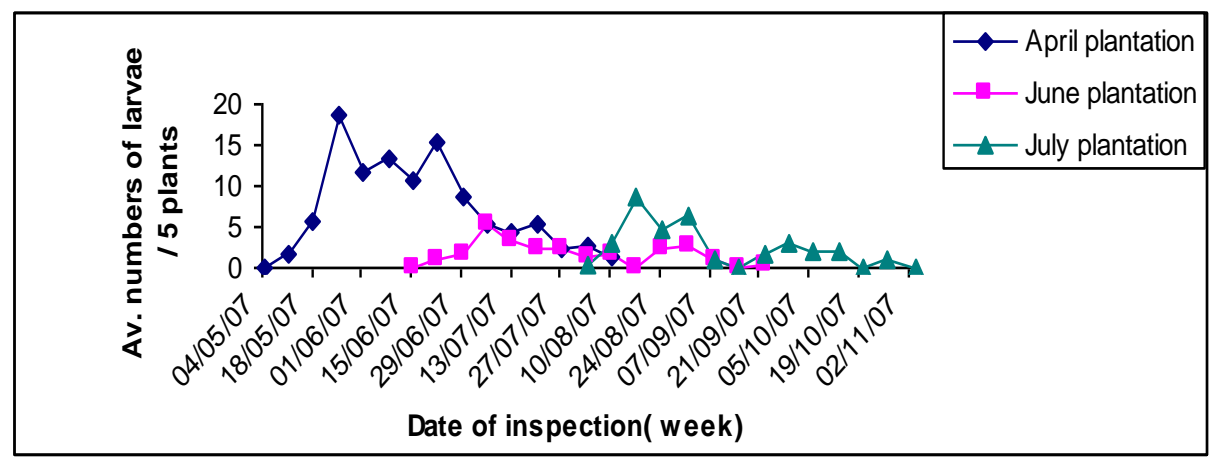

Fig (2) : Population abundance of the sugar cane stem borer, S. cretica larvae / 5 plants in three planting dates during 2007season.

Table (1): Monthly average numbers of the sugar cane stem borer, $S$. cretica larvae in three planting dates during 2006 and 2007 seasons.

\begin{tabular}{|c|c|c|c|c|c|c|}
\hline \multirow[b]{2}{*}{ Months } & \multicolumn{3}{|c|}{2006} & \multicolumn{3}{|c|}{2007} \\
\hline & $\begin{array}{c}\text { April } \\
\text { plantation }\end{array}$ & $\begin{array}{c}\text { June } \\
\text { plantation }\end{array}$ & $\begin{array}{c}\text { July } \\
\text { plantation }\end{array}$ & $\begin{array}{c}\text { April } \\
\text { plantation }\end{array}$ & $\begin{array}{c}\text { June } \\
\text { plantation }\end{array}$ & $\begin{array}{c}\text { July } \\
\text { plantation }\end{array}$ \\
\hline May & $32.8 \pm 13.2$ & - & - & $26.3 \pm 16.9$ & - & - \\
\hline Jun. & $38.2 \pm 6.3$ & $4 \pm 3.6$ & - & $48 \pm 4.6$ & $3.7 \pm 2.1$ & - \\
\hline Jul. & $6.8 \pm 2.8$ & $3.8 \pm 1.5$ & - & $17.5 \pm 2.9$ & $13.5 \pm 2.6$ & - \\
\hline Aug. & $1.5 \pm 1.5$ & $4.8 \pm 2.3$ & $17 \pm 4.4$ & $8.0 \pm 3.0$ & $5.3 \pm 1.9$ & $16.8 \pm 7.1$ \\
\hline Sep. & - & $2.3 \pm 1.7$ & $7.4 \pm 1.5$ & - & $4.0 \pm 2.5$ & $9.6 \pm 4.4$ \\
\hline Oct. & - & - & $2.3 \pm 1.1$ & - & - & $5 \pm 1.9$ \\
\hline Nov. & - & - & 0.0 & - & - & 0.0 \\
\hline Mean \pm SE & $23.5 \pm 5.5$ & $3.7 \pm 0.9$ & $8.1 \pm 2.1$ & $28.7 \pm 5.8$ & $6.8 \pm 1.5$ & $9.6 \pm 2.8$ \\
\hline \begin{tabular}{|l} 
LSD 0.05 \\
0.01 \\
0.001
\end{tabular} & \multicolumn{3}{|c|}{$\begin{array}{l}1.3 \\
1.7 \\
2.2\end{array}$} & \multicolumn{3}{|c|}{$\begin{array}{l}1.4 \\
1.9 \\
2.4\end{array}$} \\
\hline
\end{tabular}

\section{Effect of nitrogen fertilizer}

Data presented in table (2) show the effect of nitrogen fertilizer rates on the rate of infestation with S. cretica during 2006 and 2007 seasons. It was observed that, increase of nitrogen fertilizer rates led to an increase in the infestation with S. cretica. In season 2006, at the beginning of inspection, the rates of infestation were $20,20,15$ and $10 \%$ on May $18^{\text {th }}$ with four nitrogen levels 360, 260, 160 and control (zero) Kg/ Fed., respectively. The rate of infestation increased to reach the maximum in the beginning of June recording 65, 45, 45 and $20 \%$ for nitrogen levels 360, 260, 160 and control, respectively. In season 2007, at the beginning of inspection, the rates of infestation were $25,15,20$ and $10 \%$ on May $18^{\text {th }}$ with four nitrogen levels $360,260,160$ and control (zero) Kg/ Fed., respectively. The rate of infestation increased to reach the maximum at the beginning of June recording 75,50 , 50 and $35 \%$ for nitrogen levels 360, 260, 160 and control, respectively.

As a conclusion, increasing nitrogen fertilizer rates from zero to 360 $\mathrm{Kg} /$ fed. caused a significant increase in rate of infestation with $S$. cretica. When the corn plants supplied with 360, 260, 160 and zero Kg nitrogen / 
fed., the rate of infestation with $S$. cretic were ( $26.5 \pm 6.4 \%-24.6 \pm 7.1 \%)$, ( $15.0 \pm 3.9 \%-17.7 \pm 5.0 \%),(13.5 \pm 3.9 \%-14.6 \pm 4.5 \%)$ and $(7.7 \pm 1.9 \%-$ $10.1 \pm 3.3 \%)$ to four nitrogen levels during two seasons 2006 and 2007, respectively. The statistical analysis revealed, in season 2006, highly significant differences in infestation with $S$. cretica between four rates of nitrogen fertilizer. On the other hand, there was significant differences between four rates of nitrogen fertilizer.

These results agree with those obtained by Nawar et al.(1992) who found that increasing nitrogen level from 60 to $120 \mathrm{~kg} \mathrm{~N} /$ fed. caused a significant increase of infestation rate with corn borer, S. cretica. Galal et al.(1997) found that the natural infestation varied considerably and significantly from one year to another and increased with the increase in nitrogen rates. Ali et al. (2001) found that the increasing of $\mathrm{N}$ fertilizer rate favoured borer infestation. Abazied (2008) reported that the infestation was affected with the dose of nitrogen fertilizer, the high dose of nitrogen fertilizer (310 kg / fed ) increased the borer infestation more than the recommended dose $(230 \mathrm{~kg} / \mathrm{fed})$.

Table (2): Effect of nitrogen fertilizer rates on rates of infestation with the sugar cane stem borer, S. cretica during seasons 2006 and 2007.

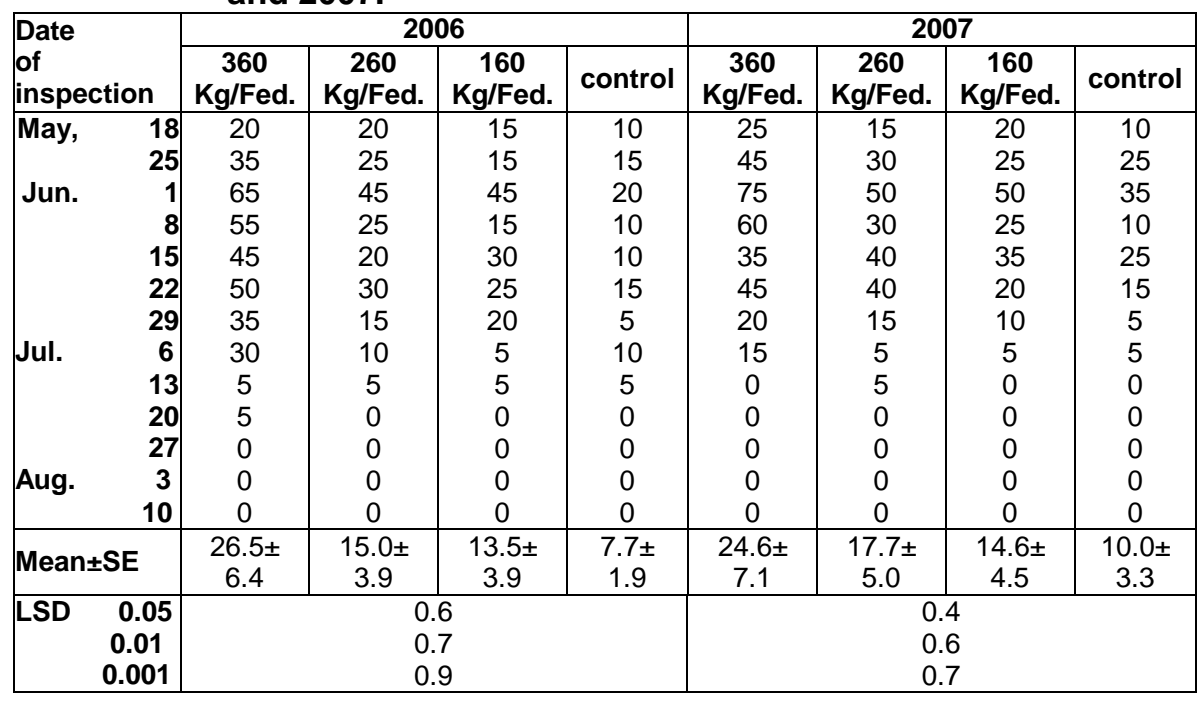

\section{Effect of planting spaces}

Data presented in table (3) show effect of planting spaces on the rate of infestation with S. cretica during 2006 and 2007 seasons. The obtained results showed that, increase of planting spaces between hills led to a decrease in S. cretica infestation. In season 2006, The infestation began in the first week of May and reached its maximum in the last week of May in the three spaces (20,25 and $30 \mathrm{~cm}$ between hills). Whereas, the highest rate of infestation was recorded in the planting space, $20 \mathrm{~cm}$ reaching $65 \%$ and the lowest infestation was recorded in space, $30 \mathrm{~cm}$ reaching $25 \%$. In season 
2007, The infestation began in the first week of May and reached its maximum in the third week of May in both planting spaces 20 and 25 while, $30 \mathrm{~cm}$ reached its maximum in the last week of May. The highest rate of infestation was recorded in the planting space, $20 \mathrm{~cm}$ reaching $60 \%$ and the lowest infestation was $35 \%$ recorded in space, $30 \mathrm{~cm}$.

As a conclusion, increasing planting spaces from 20 to $30 \mathrm{~cm}$ between hills caused insignificant decrease in the rates of infestation. The rates of infestation were $(16.3 \pm 4.9 \%-16.3 \pm 5.1 \%),(10.7 \pm 3.0 \%-12.3 \pm 4.0 \%)$ and $(9.0 \pm 2.4 \%-9.7 \pm 2.9 \%)$ to three planting spaces 20,25 and $30 \mathrm{~cm}$ during two seasons 2006 and 2007 respectively. The statistical analysis revealed insignificant differences between the three planting spaces during both seasons.

These results agree with those obtained by Tantawi et al. (1991) who found that, crowdness of sorghum hills in the field increased the borer infestation and disagree with those of Abdallah and Badawi (1990) who found that, the degree of the purple lined borer, Chilo agamemnon Bles. infestation in rice field was relatively lower at $20 \times 10 \mathrm{~cm}$ spacing than with wider spaces of $20 \times 20 \mathrm{~cm}$ or $20 \times 30 \mathrm{~cm}$.

Table (3): Effect of planting spaces on the rates of infestation with the sugar cane stem borer, S. cretica during seasons 2006 and 2007.

\begin{tabular}{|c|c|c|c|c|c|c|c|}
\hline \multirow{2}{*}{\multicolumn{2}{|c|}{$\begin{array}{l}\text { Date } \\
\text { of inspection }\end{array}$}} & \multicolumn{3}{|c|}{2006} & \multicolumn{3}{|c|}{2007} \\
\hline & & $20 \mathrm{~cm}$ & $25 \mathrm{~cm}$ & $30 \mathrm{~cm}$ & $20 \mathrm{~cm}$ & $25 \mathrm{~cm}$ & $30 \mathrm{~cm}$ \\
\hline \multirow[t]{4}{*}{ May, } & 4 & 5 & 5 & 5 & 15 & 10 & 0 \\
\hline & 11 & 20 & 20 & 10 & 35 & 35 & 20 \\
\hline & 18 & 45 & 25 & 20 & 60 & 45 & 25 \\
\hline & 25 & 65 & 35 & 25 & 50 & 35 & 35 \\
\hline \multirow[t]{5}{*}{ Jun. } & 1 & 30 & 20 & 25 & 35 & 20 & 20 \\
\hline & 8 & 20 & 25 & 5 & 20 & 35 & 15 \\
\hline & 15 & 25 & 15 & 20 & 15 & 10 & 15 \\
\hline & 22 & 20 & 10 & 10 & 0 & 5 & 5 \\
\hline & 29 & 5 & 0 & 10 & 10 & 0 & 10 \\
\hline \multirow[t]{4}{*}{ Jul. } & 6 & 0 & 5 & 5 & 0 & 0 & 0 \\
\hline & 13 & 0 & 0 & 0 & 5 & 0 & 0 \\
\hline & 20 & 0 & 0 & 0 & 0 & 0 & 0 \\
\hline & 27 & 0 & 0 & 0 & 0 & 0 & 0 \\
\hline \multirow[t]{2}{*}{ Aug. } & 3 & 0 & 0 & 0 & 0 & 0 & 0 \\
\hline & 10 & 0 & 0 & 0 & 0 & 0 & 0 \\
\hline \multicolumn{2}{|c|}{ Mean \pm SE } & $16.3 \pm 4.9$ & $10.7 \pm 3.0$ & $9.0 \pm 2.4$ & $16.3 \pm 5.1$ & $12.3 \pm 4.0$ & $9.7 \pm 2.9$ \\
\hline \multicolumn{2}{|l|}{ LSD } & \multicolumn{3}{|c|}{ ns } & \multicolumn{3}{|c|}{ ns } \\
\hline
\end{tabular}

\section{REFERENCES}

Abazied, A. A. (2008). Effect of some agricultural practices on the infestation with greater sugar cane borer, Sesamia cretica Led. in the spring plant cane and its $1^{\text {st }}$ Ratoon in upper Egypt. J. Agric. Sci. Mansoura Univ., 23(2):1499-1507. 
Abdalla, F. E. and A. T. Badawi ( 1990). The influence of certain cultural practices on rate of infestation of rice with the purple borer, Chilo agamemnon Bles. and on grain yield. J. Agric. Res. Tanta Univ., 16(2) : 323-329.

Abdalla, F. E. and S. B. Bleih (1994). Seasonal fluctuations of the corn borer insects, Sesamia cretica Led. and Ostrinia nubilalis Hub. and their chemical control. J. Agric. Res. Tanta Univ., 20(3) : 511- 523.

Abd El-Gayed, A. A. (1995). Studies on some maize insect pests and their natural enemies . M. Sc. Thesis, Fayoum Fac. Agric. Cairo Univ., 142 pp.

Abd El-Rahim, M. M.; M. I. Abd El-Fattah; A. T. Farag and M. A. Z. ElNaggar (1991). Relative susceptibility of maize cultivars to infestation by corn borers, Sesamia cretica Led. and Ostrinia nubilalis Hub. in relation to the sowing date. Minufia. J. Agric. Res. 16(1): 843-858.

Abd El-Rahman, I.; M. B. Shawer and S. M. I. Metwally (1984). Population density of major maize insects as influenced by planting date and maize variety. J. Agric. Res. Tanta Univ., 10(2) : 627- 665.

Ahmed, M. M. M. (2000). Studies on the important insect pests of maize plants and their natural enemies at Kafr El-Sheikh district. Ph. D. Thesis, Fac. Agric.Kafr El-Sheikh, Tanta Univ., 180pp.

Ali, A. G.; N. A. Abdel-Hafiz and M. A. A. Abdel-Rahman (2001). Effect of fertilization on the borer infestation in sugarcane plantation. Assiut $\mathrm{J}$. Agric. Sci.; 32(4): 19-27.

Atiyeh, R.; M. Aslam and R. Baalbaki (1996). Nitrogen fertilizer and planting date effects on insect pest population of sweet corn. Pakistan. J. Zoology. 28(2): 163-167.

El-Naggar, M. A. Z. (1991). Ecological factors influencing some insect pests diversity in maize fields. M.Sc. Thesis, Fac. Agric. Minufiya Univ., $161 \mathrm{pp}$.

El-Saadany, G. B., A. A. Amin, M. A. Salem and A. M. Salman (2000). Cultivation dates in relation to four major insect pests attacking sorghum in upper Egypt. Egypt. J. Agric. Res., 78 (5): 1937-1957.

El-Sappagh, I. A. (1998). Effect of some agricultural treatments on certain insect pests which attack corn in Egypt. M. Sc. Thesis, Fac. Agric. Moshtohor. Zagazig Univ., 125pp.

Galal. A. A.; A. A. Shenaway; F. A. El-Zeir(1997). Evaluation of some maize inbreds for resistance to stem borers under Nitrogen and phosphorus fertilizers. J. Agric. Res. Tanta Univ., 23(2):166-173.

Metwally, A. S. M. I. (2002). Evaluation of population density for corn borers and insect natural enemies on corn and rice plants. M. Sc. Thesis, Fac. Agric. Kafr El-Sheikh, Tanta Univ.,80pp.

Nawar, A. A.; M. E. Ibrahim and M. B. Attia (1992). Grain yield, yield component and infestation rates of corn borers and aphid of maize genotypes as influenced by nitrogen fertilizer. Egyptian J. Of Agronomy. 17(1-2): 41-58. 
Tantawi, A. M.; M. F. El-Metwally; K. A. Mowafy and A. M. Soliman(1991). Sorghum borer Sesamia cretica Led. infestation in relation to certain cultural practices including: planting date, nitrogen rates and planting spacing. Proc. $4^{\text {th }}$ Arab Cong. of plant prot., vol. 2: 424-429.

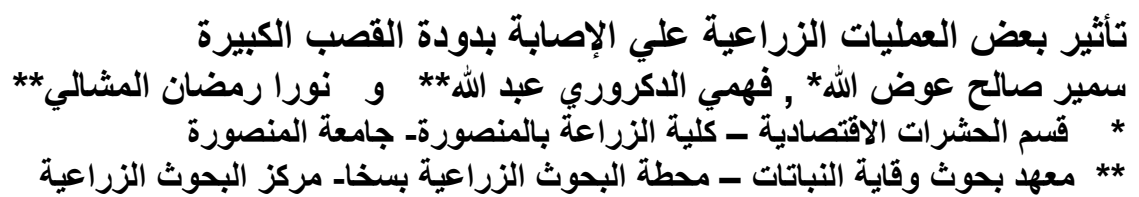

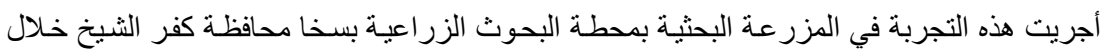

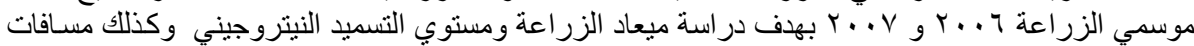

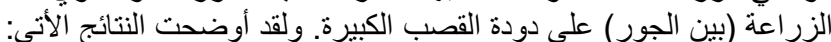

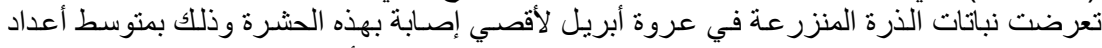

و ذلك, 0

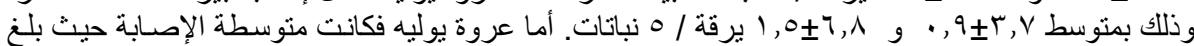

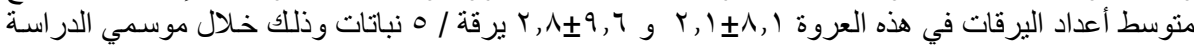

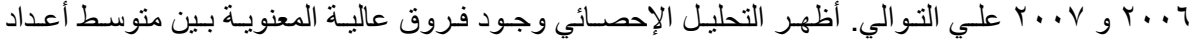

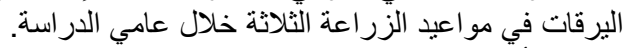

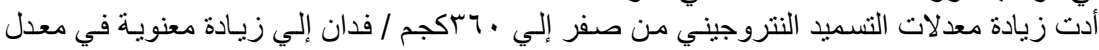

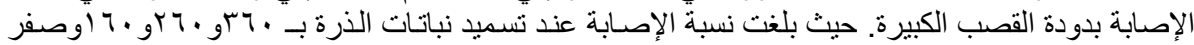
كج ـ

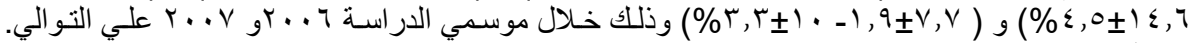

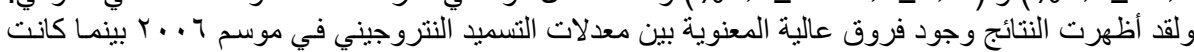

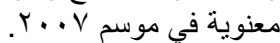

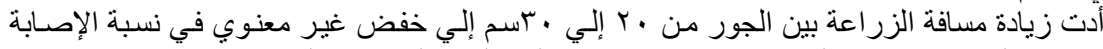

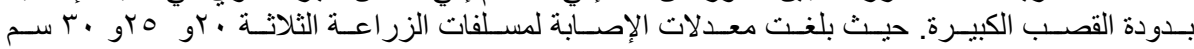

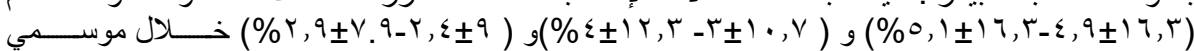

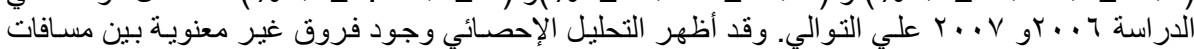

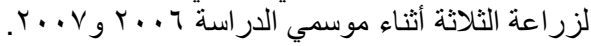

